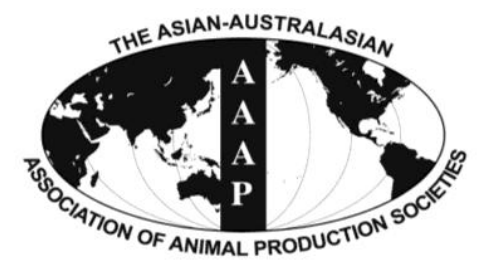

Asian-Aust. J. Anim. Sci.

Vol. 25, No. 11 : 1546-1552 November 2012

http://dx.doi.org/10.5713/ajas.2012.12248

www.ajas.info

pISSN 1011-2367 elSSN 1976-5517

\title{
Effect of Alcohol Fermented Feed on Lactating Performance, Blood Metabolites, Milk Fatty Acid Profile and Cholesterol Content in Holstein Lactating Cows
}

\author{
X. Z. Li ${ }^{1, a}$, B. K. Park ${ }^{2, a}$, C. G. Yan ${ }^{1}$, J. G. Choi ${ }^{3}$, J. S. Ahn and J. S. Shin* \\ College of Animal Life Science, Kangwon National University, Chuncheon 200-701, Korea
}

\begin{abstract}
A feeding experiment with 40 lactating Holstein cows and 4 dietary treatments was conducted to investigate supplementation with different levels of alcohol fermented feed to the TMR on lactating performance, blood metabolites, milk fatty acid profile and cholesterol concentration of blood and milk. Forty Holstein lactating cows (106 $\pm 24 \mathrm{~d}$ post-partum; mean \pm SD) were distributed into four groups and randomly assigned to one of four treatments with each containing 10 cows per treatment. The treatment supplemented with TMR (DM basis) as the control (CON), and CON mixed with alcohol-fermented feeds (AFF) at a level of 5\%, 10\% and $15 \%$ of the TMR as T1, T2 and T3, respectively. Dry matter intake and milk yield were not affected by supplementation of AFF. An increased 4\% FCM in the milk occurred in cows fed T3 diet compared with CON, while T1 and T2 diets decreased 4\% FCM in a dose dependent manner. Supplementation of AFF increased the concentration of albumin, total protein (TP), ammonia, and high density lipoprotein-cholesterol in serum compared with CON. In contrast, supplementation with AFF clearly decreased concentration of blood urea nitrogen (BUN) and total cholesterol (TC) compare with CON. AFF supplementation increased the proportion of C18:1n9 and C18:2n6 compared to CON. A decrease in the concentration of saturated fatty acid (SFA) for T1, T2 and T3 resulted in an increased unsaturated fatty acid (USFA) to SFA ratio compared to CON. Concentration of cholesterol in milk fat was reduced in proportion to the supplemental level of AFF. Feeding a diet supplemented with a moderate level AFF to lactating cows could be a way to alter the feed efficiency and fatty acid profile of milk by increasing potentially human consumer healthy fatty acid without detrimental effects on feed intake and milk production. A substantially decreased cholesterol proportion in milk induced by supplementation AFF suggests that alcohol fermented feed may improve milk cholesterol levels without any negative effects in lactating cows. (Key Words: Alcohol Fermented Feed, Lactating Cows, Lactating Performance, Blood Metabolite, Fatty Acid, Cholesterol)
\end{abstract}

\section{INTRODUCTION}

Alcohol is one of the important intermediates formed during fermentation of forage and agriculture by-products. A wide range of alcohol concentrations can be found in grass and maize silages (Dulphy and Demarquilly, 1981; Byers et al., 1982; Rooke et al., 1988). Alcohol, introduced in the rumen by diets, is known to be only partially (about $20 \%$ ) transformed to VFA by the rumen microorganisms

\footnotetext{
* Corresponding Author: J. S. Shin. Tel: +82-33-250-8628, Fax: +82-33-244-2532, E-mail: jsshin@kangwon.ac.kr

${ }^{1}$ Department of Animal Science, College of Agriculture Science, Yanbian University, Yanji, JiLin, 13302, China.

${ }^{2}$ Nonghyup Feed Co., LTD., Seoul 134-763, Korea.

${ }^{3}$ Deahan Livestock and Feed Co., LTD. BukSung-Dong, 1-Ka, Chung-Ku, Incheon 400-201, Korea.

${ }^{\mathrm{a}}$ Both authors contributed equally.

Submitted May 7, 2012; Accepted Jun. 26, 2012; Revised Jul. 27, 2012
}

(Durix et al., 1991) and most alcohol is known to be absorbed through the rumen wall (Burning and Yokoyama, 1988). In the rumen, alcohols also can be synthesized by fungi (Teunissen et al., 1992) and bacteria (Laukova and Marounek, 1992), and production of alcohol is an electron sink in fermentation (Teunissen et al., 1992), in agreement with the observed accumulation of alcohols with high starch intake (Allison et al., 1964). Alcohols are removed from the rumen by microbial metabolism and absorption (Jean-Blain et al., 1992).

The addition of an adequate amount of alcohol to beef diets has been known to be desirable to improve feed efficiency and meat quality. Shin et al. (1995) observed a higher alcohol concentration in steers fed alcohol fermented feed (AFF), and it was speculated that there was an amount of alcohol absorption from AFF diet into the blood via the rumen wall. Yan (1998) found beneficial effects of alcoholfermented feeds for improving the marbling score of 
Korean native steers, and Lin (2001) observed that production of total volatile fatty acid and propionate in rumen were affected by supplementation of alcohol-added feed or alcohol-fermented feed, and may improve body weight gain of Korean native steers by decreased protein degradation as well as increased fat synthesis (Lin et al., 2005).

The multiple inputs and outputs of alcohols indicate that alcohol metabolism in ruminants represents a complex system, and the metabolism effects of alcohols by lactating cows is not well understood and has been sparsely described. The present study was undertaken to investigate supplementation of different level of alcohol fermented feed to the TMR on lactating performance, blood metabolites and milk fatty acid profile in Holstein lactating cows.

\section{MATERIALS AND METHODS}

\section{Animals and diets}

All experimental procedures for this study were approved by the Institutional Animal Care and Use Committee of Kangwon National University, Korea. The study was conducted with forty Holstein lactating cows (106 \pm 24 d post-partum; mean \pm SD) between July 3 and November 11 of 2010 . Holstein cows were distributed into groups of four to ensure uniform distribution based on parity, body weight and daily milk yield and assigned to one of four treatments with each containing 10 cows per treatment. Alcohol fermented feed (AFF) was prepared by mixing $45 \%$ cracked corn, $45 \%$ brewery meal, $5 \%$ molasses and $5 \%$ live yeast. Then the whole mixture was fermented at $30^{\circ} \mathrm{C}$ for $48 \mathrm{~h}$. Concentration of alcohol was determined using the alcohol auto-analyzer (Pet-109, Atago, USA). The treatment supplemented with TMR (dry matter basis) as the control (CON), and CON mixed with alcohol-fermented feeds (AFF) at a level of 5\%,10\% and $15 \%$ of the TMR as T1, T2 and T3, respectively. Lactating Holstein cows were fed 5.0 kg (DM) of TMR per meal twice daily at 08:00 and 18:00 $\mathrm{h}$ in equal amounts individually prior to milking. Experimental TMR and AFF feed were supplied by DEAHAN feed Co., LTD in Korea. The feeding level of the TMR was set based on the nutrient requirements for lactating cows (NRC, 2001). The ingredients and chemical composition of the experimental diets are presented in Table 1.

\section{Feed sampling and measurements}

Feeds and refusals were collected and amounts were recorded $30 \mathrm{~min}$ prior to morning feeding at 08:00 $\mathrm{h}$ daily to estimate dry matter intake (DMI). Samples of diets and orts were collected twice per period for chemical analyses. Feed efficiency was calculated by the milk yield per day divided by the feed intake per day of the cow. Feed intake
Table 1. Ingredients and chemical composition of experimental diets

\begin{tabular}{|c|c|c|c|c|}
\hline Items & $\mathrm{CON}$ & $\mathrm{T} 1$ & $\mathrm{~T} 2$ & T3 \\
\hline \multicolumn{5}{|l|}{ Ingredients (DM basis, \%) } \\
\hline Timothy hay & 9.68 & 9.19 & 8.71 & 8.03 \\
\hline Klein hay & 4.84 & 4.60 & 4.35 & 4.11 \\
\hline Alfalfa hay & 4.84 & 4.60 & 4.35 & 4.11 \\
\hline Oat hay & 3.23 & 3.07 & 2.91 & 2.74 \\
\hline Cottonseed whole & 4.84 & 4.60 & 4.35 & 4.11 \\
\hline Beet pulp & 3.23 & 3.07 & 2.91 & 2.74 \\
\hline Brewers grain, wet & 9.68 & 9.19 & 8.71 & 8.23 \\
\hline Corn, Flake & 3.23 & 3.07 & 2.91 & 2.74 \\
\hline Rice straw & 3.23 & 3.07 & 2.91 & 2.74 \\
\hline $\begin{array}{l}\text { Commercial feed } \\
\text { (CP 19.5\%, TDN 73\%) }\end{array}$ & 30.7 & 29.1 & 27.7 & 26.0 \\
\hline Water & 22.5 & 21.4 & 20.3 & 19.2 \\
\hline AFF & & 5 & 10 & 15 \\
\hline Total & 100 & 100 & 100 & 100 \\
\hline \multicolumn{5}{|l|}{$\begin{array}{l}\text { Chemical or calculated } \\
\text { composition (DM basis) }\end{array}$} \\
\hline Dry matter $(\%)$ & 63.7 & 62.0 & 60.8 & 59.2 \\
\hline NEL (Mcal/kg) & 1.67 & 1.69 & 1.69 & 1.72 \\
\hline TDN (\%) & 63.1 & 64.0 & 64.6 & 65.5 \\
\hline $\mathrm{CP}(\%)$ & 16.7 & 16.5 & 16.4 & 16.3 \\
\hline $\mathrm{EE}(\%)$ & 4.94 & 4.92 & 4.90 & 4.87 \\
\hline Ash (\%) & 7.48 & 7.39 & 7.33 & 7.24 \\
\hline $\operatorname{NDF}(\%)$ & 43.4 & 42.3 & 41.6 & 40.5 \\
\hline $\operatorname{ADF}(\%)$ & 24.7 & 23.8 & 23.4 & 22.7 \\
\hline NSC (\%) & 28.1 & 29.4 & 30.2 & 31.5 \\
\hline UIP (\%) & 32.4 & 33.0 & 33.4 & 34.1 \\
\hline $\operatorname{SIP}(\%)$ & 21.4 & 21.2 & 21.0 & 20.7 \\
\hline Forage (\%) & 46.8 & 45.1 & 44.0 & 42.3 \\
\hline $\mathrm{Ca}(\%)$ & 0.74 & 0.72 & 0.71 & 0.68 \\
\hline $\mathrm{P}(\%)$ & 0.38 & 0.38 & 0.38 & 0.37 \\
\hline Alcohol (\%) & & 0.60 & 1.20 & 1.80 \\
\hline
\end{tabular}

T1 = Fed TMR supplemented with alcohol-fermented feeds (AFF) at a level of $5 \%$ of the TMR; T2 $=$ Fed TMR supplemented with AFF at a level of $10 \%$ of the TMR; T3 = Fed TMR supplemented with AFF at a level of $15 \%$ of the TMR; $\mathrm{NEL}=$ Net energy for lactation; TDN $=$ Total digestible nutrition; UIP = Un-degraded intake protein; SIP = Soluble intake protein; $\mathrm{NDF}=$ Neutral detergent fiber; $\mathrm{NDFF}=\mathrm{NDF}$ from forage; $\mathrm{ADF}=$ Acid detergent fiber; NSC $=$ Non-structure carbohydrates.

was also calculated by the residual feed deducted from the total supplied feed. AOAC (1995) procedures were used to determine dry matter (DM), crude protein (CP), ether extract (EE), ash, $\mathrm{Ca}$ and $\mathrm{P}$. Feed NDF and ADF were analyzed according to the method initially described by Van Soest et al. (1991).

The AFF samples for alcohol determination were obtained after dissolution at $4^{\circ} \mathrm{C}$ for $30 \mathrm{~min}$ followed by 5 $\mathrm{X}$ dilutions with distilled water. Then, the samples were centrifuged at 3,000 rpm for 5 min and supernatants were collected. Alcohol concentration in the supernatant was analyzed by glucose analyzer (YSI 2700, USA) with YSI 


\section{2,386 alcohol oxidase membrane.}

\section{Milk collection and measurements}

The Holstein cows were machine-milked (Type MES, No. 843410, Marice Animal Husbandry Machinery Technology Co., Ltd. Wenzhou, China) twice daily at 08:20 and 18:20 h. Milk production was recorded daily, and 100 $\mathrm{ml}$ of milk samples were collected once per month throughout the experiment. The a.m. and p.m. milk samples $(50 \mathrm{ml} / 50 \mathrm{ml}, \mathrm{v} / \mathrm{v})$ were then combined within cow on every sampling day for analysis of milk composition. Milk total solid, protein, fat, lactose, solid non fat, milk urea nitrogen (MUN) and somatic cell counts (SCC) were analyzed with infrared analysis (Foss Milkoscan FT120; Foss Food Technology Corp., Danmark).

Feed efficiency, 4\% FCM and 4\% FCM feed efficiency were calculated with the following equations:

$$
\begin{aligned}
& \text { Feed efficiency }=\text { milk yield }(\mathrm{kg} / \mathrm{d}) / \text { feed intake }(\mathrm{kg} / \mathrm{d}) \\
& \begin{aligned}
4 \% \mathrm{FCM}= & 0.4 \times \text { actual milk yield }(\text { in } \mathrm{kg} / \mathrm{d}) \\
& +15 \times \text { milk fat }(\text { in } \mathrm{kg} / \mathrm{d})
\end{aligned}
\end{aligned}
$$

\section{$4 \%$ FCM feed efficiency $=4 \% \mathrm{FCM} /$ feed intake $(\mathrm{kg} / \mathrm{d})$}

Lipids in the milk fat were extracted using Folch's solution (1957), and methylation of fatty acid (FAME) was prepared according to the method of Lepage and Roy (1986) prior to injection into a gas chromatograph (GC-17A, SHIMADZU, Japan) equipped with a flame ionization detector and a $30 \mathrm{~m}$ fused silica capillary column (Supelcowax $^{\mathrm{TM}}-10,0.32 \mathrm{~mm}$ i.d. Supelco inc., Bellefone, PA, USA). Ultra-high purity He was used as a carrier gas at a flow rate of $1 \mathrm{ml} / \mathrm{min}$. Injector and detector temperatures were 270 and $280^{\circ} \mathrm{C}$, respectively. The split ratio of the flame ionization detector was 1:50. The oven temperature was scheduled from $190^{\circ} \mathrm{C}$ for $5 \mathrm{~min}$ and increased to $230^{\circ} \mathrm{C}$ at a rate of $2^{\circ} \mathrm{C} / \mathrm{min}$, and was maintained at $230^{\circ} \mathrm{C}$ for $25 \mathrm{~min}$. A variety of fatty acid standard mixtures $(\mathrm{Nu}$ Check Prep; Elysian, MN), were used to identify components and assist in the calculation of response factors. Total cholesterol concentration in milk fat was determined by a gas chromatograph (GC-17A, SHIMADZU, Japan) equipped with a flame ionization detector. The oven temperature was scheduled from $290^{\circ} \mathrm{C}$ for $5 \mathrm{~min}$ and increased to $310^{\circ} \mathrm{C}$ at a rate of $2^{\circ} \mathrm{C} / \mathrm{min}$, and was maintained at $310^{\circ} \mathrm{C}$ for $5 \mathrm{~min}$. The temperatures of the injector and detector were maintained at $270^{\circ} \mathrm{C}$ and $300^{\circ} \mathrm{C}$, respectively. A 30-m fused silica capillary column (HP-1, Crosslinked Methyl Silicone Gum, 0.32 mm i.d. USA) was used. Identification and quantification were carried out by the external standard method following injection of a cholesterol standard (Supelco 47127-U, USA) of known concentration.

\section{Blood collection and analyses}

Ten milliliters of blood was taken from the jugular vein into evacuated test tubes (Vacutainer, Becton 93 Dickinson Vacutainer Systems, Rutherford, NJ, USA) containing K3EDTA $1 \mathrm{~h}$ before the morning feeding (08:00 h) once per month throughout the experimental period for analysis of blood metabolites. Blood was centrifuged at 3,000 $\times$ g for 15 min at $4^{\circ} \mathrm{C}$, and serum was stored at $-70^{\circ} \mathrm{C}$ until used for assay. Contents of albumin, blood urea nitrogen (BUN), total protein (TP), creatine, glucose, triglycerides (TG), total cholesterol (TC), HDL-cholesterol (HDL-C), calcium, phosphorus and magnesium in serum were measured using an automated blood serum biochemical analyzer (T Express Plus, USA). The ammonia content of the samples was determined according to the method of Chaney and Marbech (1962) whereas lactic acid content was analyzed by UV spectrophotometer (Hitachi, Japan). Serum gamma gluctamyl transpeptidas (GGT), glutamate oxaloacetate transaminase (GOT) and glutamate pyruvate transaminase (GPT) concentrations of the blood samples were analyzed by Green Cross MS in Korea.

\section{Statistical analysis}

Results obtained from the experiment were analyzed by one-way ANOVA for variance using the GLM (General Linear Model) procedure of the SAS (2004) 9.1 Soft Ware Package and authorized synonymy between averages were determined by Duncan's multiple range test method. Significant differences were accepted if $\mathrm{p}<0.05$.

\section{RESULTS}

\section{Dry matter intake, milk yield, milk components and apparent feed efficiency}

The DMI and milk yield were not affected by supplementation of AFF (Table 2). Similarly, TMR containing AFF did not alter the contents of total solid, protein, fat, lactose, solid non fat and MUN in milk. An increased 4\% FCM in the milk occurred in cows fed T3 diets compared to $\mathrm{CON}$, while $\mathrm{T} 1$ and $\mathrm{T} 2$ diets decreased $4 \%$ FCM and the reduction was in a dose dependent matter. However, apparent feed efficiency of converting feed into energy-corrected milk did not differ among the treatments. TMR containing AFF also decreased milk SCC compared with control treatment.

\section{Blood metabolite concentrations}

Cows, fed the TMR containing AFF had an increased $(p<0.05)$ concentration of albumin, total protein (TP), ammonia, and high density lipoprotein cholesterol (HDLC) 
Table 2. Performance of Holstein lactating cows as influenced by supplementation of alcohol fermented feedstuffs to the TMR

\begin{tabular}{|c|c|c|c|c|}
\hline Items & $\mathrm{CON}$ & $\mathrm{T} 1$ & $\mathrm{~T} 2$ & $\mathrm{~T} 3$ \\
\hline Dry matter intake (kg) & $19.4 \pm 0.41^{\mathrm{c}}$ & $20.6 \pm 0.46^{\mathrm{b}}$ & $21.9 \pm 0.34^{\mathrm{a}}$ & $22.2 \pm 0.43^{\mathrm{a}}$ \\
\hline Milk yield $(\mathrm{kg} / \mathrm{d})$ & $20.1 \pm 0.64^{b}$ & $16.1 \pm 0.52^{\mathrm{c}}$ & $18.9 \pm 0.84^{\mathrm{b}}$ & $24.3 \pm 0.58^{\mathrm{a}}$ \\
\hline Feed efficiency & $1.04 \pm 0.02^{\mathrm{b}}$ & $0.78 \pm 0.02^{\mathrm{d}}$ & $0.87 \pm 0.01^{\mathrm{c}}$ & $1.09 \pm 0.01^{\mathrm{a}}$ \\
\hline 4\% FCM yield & $20.9 \pm 0.41^{\mathrm{a}}$ & $17.3 \pm 0.49^{c}$ & $19.0 \pm 0.31^{\mathrm{b}}$ & $21.1 \pm 0.57^{\mathrm{a}}$ \\
\hline 4\% FCM feed efficiency & $0.96 \pm 0.03$ & $0.93 \pm 0.08$ & $0.98 \pm 0.04$ & $1.15 \pm 0.06$ \\
\hline Total solid (\%) & $13.0 \pm 0.15$ & $12.3 \pm 0.15$ & $12.2 \pm 0.14$ & $12.2 \pm 0.19$ \\
\hline Milk protein $(\%)$ & $3.41 \pm 0.05$ & $3.37 \pm 0.06$ & $3.36 \pm 0.07$ & $3.32 \pm 0.09$ \\
\hline Milk fat (\%) & $4.10 \pm 0.13$ & $4.04 \pm 0.09$ & $4.01 \pm 0.07$ & $4.02 \pm 0.10$ \\
\hline Milk lactose (\%) & $4.71 \pm 0.02$ & $4.67 \pm 0.03$ & $4.71 \pm 0.03$ & $4.75 \pm 0.04$ \\
\hline Solid non fat (\%) & $8.55 \pm 0.06$ & $8.48 \pm 0.06$ & $8.49 \pm 0.08$ & $8.48 \pm 0.09$ \\
\hline MUN (mg/dl) & $14.0 \pm 0.67$ & $15.4 \pm 0.60$ & $13.6 \pm 0.60$ & $15.1 \pm 0.74$ \\
\hline SCC. $\left(10^{3} / \mathrm{ml}\right)$ & $458 \pm 88.14^{\mathrm{a}}$ & $285 \pm 71.24^{\mathrm{b}}$ & $255 \pm 77.55^{\mathrm{b}}$ & $213 \pm 17.97^{\mathrm{c}}$ \\
\hline
\end{tabular}

$\overline{\mathrm{a}, \mathrm{b}, \mathrm{c}}$ Means within a row with different superscript differ $(\mathrm{p}<0.05)$.

$\mathrm{CON}=$ The dairy Holstein cows were fed TMR only; T1 = Fed TMR supplemented with alcohol-fermented feeds (AFF) at a level of 5\% of the TMR; T2 = Fed TMR supplemented with AFF at a level of 10\% of the TMR; T3 = Fed TMR supplemented with AFF at a level of $15 \%$ of the TMR; $4 \%$ FCM = Energy corrected yield corresponding to milk containing $4 \%$ fat; MUN = Milk urea nitrogen; SCC = Somatic cell counts; Feed efficiency = Milk yield/feed intake; $4 \%$ FCM feed efficiency $=4 \%$ FCM yield/feed intake.

in their serum compared with CON (Table 3), but there was no difference among $\mathrm{T} 1, \mathrm{~T} 2$ and $\mathrm{T} 3$. In contrast, supplementation with AFF clearly decreased concentration of blood urea nitrogen (BUN) and total cholesterol (TC) in serum compared with CON, and the lowest TC concentration was observed in $\mathrm{T} 3$ diets. The concentration of creatinine, total triglyceride (TG), $\mathrm{Ca}, \mathrm{P}$ and $\mathrm{Mg}$ in serum was not influenced by the TMR containing AFF. AFF did not affect the concentration of GGT, GPT and GOT in serum of Holstein cows (Table 3 ).

\section{Fatty acid profile and cholesterol concentration in milk fat}

The AFF supplementation increased the proportion of C18:1n9 and C18:2n6 compared to CON (Table 4). A decrease $(\mathrm{p}<0.05)$ in the content of saturated fatty acid (SFA) for T1, T2 and T3 treatments resulted in an increased unsaturated fatty acid (USFA) to SFA ratio compared to CON. Supplementation with AFF also decreased concentration of cholesterol in milk fat without difference

Table 3. Serum metabolites as influenced by supplementation of alcohol fermented feedstuffs to the TMR in Holstein lactating cows

\begin{tabular}{|c|c|c|c|c|}
\hline Items & $\mathrm{CON}$ & $\mathrm{T} 1$ & $\mathrm{~T} 2$ & $\mathrm{~T} 3$ \\
\hline$\overline{\text { Albumin }(\mathrm{mg} / \mathrm{dl})}$ & $3.45 \pm 0.04^{\mathrm{b}}$ & $3.57 \pm 0.04^{\mathrm{a}}$ & $3.58 \pm 0.03^{\mathrm{a}}$ & $3.67 \pm 0.04^{\mathrm{a}}$ \\
\hline BUN (mg/dl) & $19.5 \pm 0.66^{\mathrm{a}}$ & $18.2 \pm 0.64^{\mathrm{b}}$ & $18.1 \pm 0.61^{\mathrm{b}}$ & $18.1 \pm 0.64^{\mathrm{b}}$ \\
\hline $\mathrm{TP}$ (mg/dl) & $7.28 \pm 0.09^{\mathrm{b}}$ & $7.78 \pm 0.09^{\mathrm{a}}$ & $7.77 \pm 0.09^{\mathrm{a}}$ & $7.68 \pm 0.09^{\mathrm{a}}$ \\
\hline Ammonia (mg/dl) & $155 \pm 8.89^{\mathrm{b}}$ & $172 \pm 8.66^{\mathrm{a}}$ & $166 \pm 8.27^{\mathrm{a}}$ & $168 \pm 8.66^{\mathrm{a}}$ \\
\hline Creatinine (mg/dl) & $0.77 \pm 0.01$ & $0.77 \pm 0.02$ & $0.80 \pm 0.02$ & $0.83 \pm 0.02$ \\
\hline Glucose (mg/dl) & $53.4 \pm 1.26$ & $53.5 \pm 1.23$ & $52.5 \pm 1.17$ & $49.7 \pm 1.23$ \\
\hline $\mathrm{TC}(\mathrm{mg} / \mathrm{dl})$ & $246 \pm 12.06^{\mathrm{a}}$ & $227 \pm 11.75^{\mathrm{b}}$ & $228 \pm 11.21^{\mathrm{b}}$ & $194 \pm 11.75^{\mathrm{c}}$ \\
\hline $\mathrm{TG}(\mathrm{mg} / \mathrm{dl})$ & $4.79 \pm 1.06$ & $5.27 \pm 1.04$ & $5.19 \pm 0.99$ & $4.93 \pm 1.04$ \\
\hline HDLC (mg/dl) & $132 \pm 6.61^{\mathrm{c}}$ & $157 \pm 6.67^{\mathrm{a}}$ & $148 \pm 4.17^{\mathrm{b}}$ & $166 \pm 2.20^{\mathrm{a}}$ \\
\hline $\mathrm{Ca}(\mathrm{mg} / \mathrm{dl})$ & $10.7 \pm 0.21$ & $11.1 \pm 0.20$ & $11.2 \pm 0.20$ & $10.7 \pm 0.21$ \\
\hline $\mathrm{P}(\mathrm{mg} / \mathrm{dl})$ & $5.19 \pm 0.20$ & $5.29 \pm 0.19$ & $5.51 \pm 0.18$ & $5.24 \pm 0.19$ \\
\hline $\operatorname{Mg}(\mathrm{mg} / \mathrm{dl})$ & $2.50 \pm 0.07$ & $2.45 \pm 0.07$ & $2.54 \pm 0.07$ & $2.48 \pm 0.07$ \\
\hline GGT $(\mu / L)$ & $37.4 \pm 2.24$ & $42.0 \pm 2.18$ & $36.9 \pm 2.08$ & $31.2 \pm 2.18$ \\
\hline $\operatorname{GPT}(\mu / \mathrm{L})$ & $32.4 \pm 1.35$ & $32.4 \pm 1.32$ & $34.2 \pm 1.26$ & $35.6 \pm 1.32$ \\
\hline $\operatorname{GOT}(\mu / \mathrm{L})$ & $68.6 \pm 2.34$ & $71.4 \pm 2.28$ & $69.9 \pm 2.18$ & $77.6 \pm 2.28$ \\
\hline
\end{tabular}

$\overline{\mathrm{a}, \mathrm{b}, \mathrm{c}, \mathrm{d}}$ Means within a row with different superscript differ $(\mathrm{p}<0.05)$.

$\mathrm{CON}=$ The dairy Holstein cows were fed TMR only; T1 = Fed TMR supplemented with alcohol-fermented feeds (AFF) at a level of 5\% of the TMR; T2 = Fed TMR supplemented with AFF at a level of $10 \%$ of the TMR; T3 = Fed TMR supplemented with AFF at a level of $15 \%$ of the TMR; BUN = Blood urea nitrogen; TP = Total protein; TG = Triglyceride; $\mathrm{TC}=$ Total Cholesterol; HDLC = High density lipoprotein-cholesterol; GGT = Gamma glutamyl transpeptidas; GPT = Glutamic pyruvic transaminase; GOT = Glutamic oxaloacetic transaminase. 
Table 4. Fatty acid profile in milk fat ( $\mathrm{g} / 100 \mathrm{~g}$ FA) of Holstein lactating cows as influenced by supplementation of alcohol fermented feedstuffs to the TMR

\begin{tabular}{|c|c|c|c|c|}
\hline & $\mathrm{CON}$ & $\mathrm{T} 1$ & $\mathrm{~T} 2$ & $\mathrm{~T} 3$ \\
\hline Lauric acid, C12:0 & $1.21 \pm 0.03$ & $0.98 \pm 0.07$ & $1.07 \pm 0.10$ & $1.13 \pm 0.05$ \\
\hline Capric acid, C14:0 & $12.9 \pm 0.83$ & $11.8 \pm 1.63$ & $11.6 \pm 1.13$ & $11.4 \pm 1.96$ \\
\hline Palmtic acid, C16:0 & $35.6 \pm 1.60$ & $35.6 \pm 2.67$ & $35.9 \pm 3.55$ & $34.7 \pm 3.73$ \\
\hline Palmitoleic acid, C16:1 & $2.68 \pm 0.27$ & $2.95 \pm 0.48$ & $3.04 \pm 0.53$ & $2.88 \pm 0.68$ \\
\hline Stearic acid, C18:0 & $18.9 \pm 1.09$ & $16.3 \pm 1.99$ & $15.9 \pm 2.28$ & $17.5 \pm 7.94$ \\
\hline Oleic acid, C18:1n9 & $26.8^{\mathrm{b}} \pm 0.66$ & $28.3^{\mathrm{a}} \pm 0.47$ & $29.6^{\mathrm{a}} \pm 0.84$ & $29.2^{\mathrm{a}} \pm 0.66$ \\
\hline Linoleic acid, C18:2n6 & $2.87^{\mathrm{c}} \pm 0.37$ & $3.14^{\mathrm{b}} \pm 0.59$ & $3.19^{\mathrm{b}} \pm 0.35$ & $3.44^{\mathrm{a}} \pm 0.53$ \\
\hline$\alpha$-Linolenic acid, C18:3n & $0.69 \pm 0.11$ & $0.62 \pm 0.20$ & $0.69 \pm 0.11$ & $0.65 \pm 0.15$ \\
\hline Arachidonic acid, C20:4n6 & $0.29 \pm 0.05$ & $0.29 \pm 0.09$ & $0.30 \pm 0.04$ & $0.28 \pm 0.07$ \\
\hline Saturated fatty acid (SFA) & $67.0^{\mathrm{a}} \pm 1.17$ & $64.6^{\mathrm{b}} \pm 0.68$ & $64.5^{\mathrm{b}} \pm 0.71$ & $64.7^{\mathrm{b}} \pm 0.98$ \\
\hline Unsaturated fatty acid (USFA) & $33.4^{\mathrm{b}} \pm 1.21$ & $35.3^{\mathrm{a}} \pm 1.32$ & $36.5^{\mathrm{a}} \pm 1.18$ & $35.4^{\mathrm{a}} \pm 1.03$ \\
\hline USFA/SFA & $0.49^{\mathrm{b}} \pm 0.03$ & $0.55^{\mathrm{a}} \pm 0.04$ & $0.57^{\mathrm{a}} \pm 0.07$ & $0.55^{\mathrm{a}} \pm 0.04$ \\
\hline
\end{tabular}

$\overline{a, b, c}$ Means within a row with different superscript differ $(\mathrm{p}<0.05)$

$\mathrm{CON}=$ The dairy Holstein cows were fed TMR only; T1 = Fed TMR supplemented with alcohol-fermented feeds (AFF) at a level of 5\% of the TMR; $\mathrm{T} 2=$ Fed TMR supplemented with AFF at a level of $10 \%$ of the TMR; T3 = Fed TMR supplemented with AFF at a level of $15 \%$ of the TMR.

among the $\mathrm{T} 1, \mathrm{~T} 2$ and $\mathrm{T} 3$ treatments compared to $\mathrm{CON}$ (Figure 1).

\section{DISCUSSION}

One of the factors which influence DMI of ruminants is the net energy density of the diet, and alcohol in diets is known to be transformed to VFA by the rumen microorganisms (Andree et al., 1991), and most alcohol is known to be absorbed through the rumen wall (Burning and Yokoyama, 1988). In our current study, an increased DMI and milk yield occurred bin T3, and the increase was dose dependent with an increasing level of AFF. This may due to increased net intake of alcohol, however, milk protein, fat and lactose were not altered whrn the TMR contained AFF. Similar results occurred in lactating cows when fed corn silages with various alcohol concentrations in TMR (Kristensen et al., 2007). However, Randby et al. (1999) found that when cows received ethanol at a daily dose of $600 \mathrm{~g}$ in well-fermented grass silage, milk yields decreased slightly, milk fat and protein increased but lactose decreased. Such differences in milk composition secretion could be related to the differences in alcohol feed type and its effects on rumen fermentation metabolism. Furthermore, the highest feed efficiency and 4\% FCM in the T3 treatment among the treatments could be due to the large amount of ethanol can be readily utilized by dairy cows (Durix et al., 1991). The lower SCC in milk and an increased milk yield when TMR contained AFF compared with CON treatment in our study indicates that alcohol fermented feed may improve milk quality and milk production.

In ruminants, energy metabolism and blood metabolites

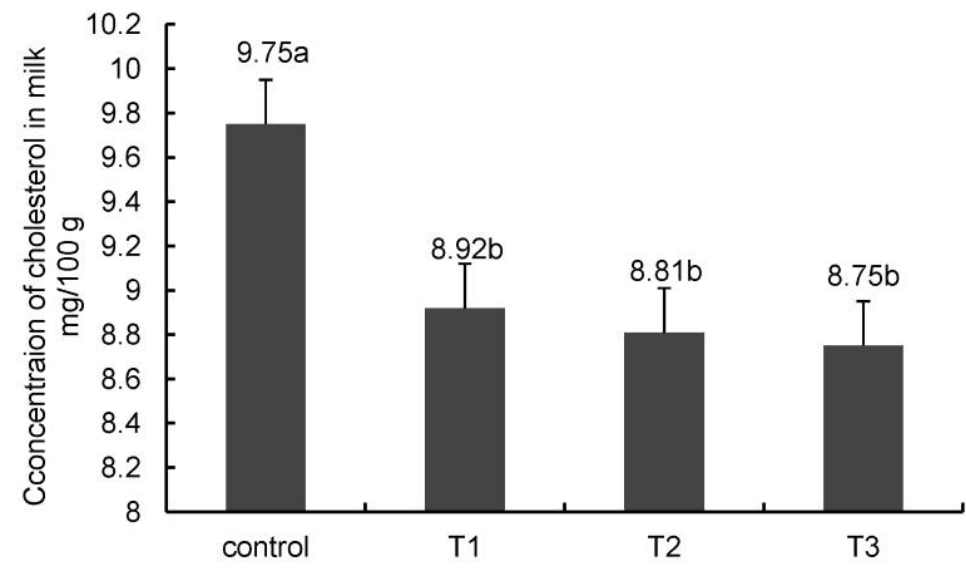

Figure 1. Concentration of cholesterol in milk as influenced by supplementation of alcohol fermented feedstuffs to the TMR in Holstein lactating cows. Control: The dairy Holstein cows were fed TMR only, T1: Fed TMR supplemented with alcohol-fermented feed (AFF) at a level of 5\% of the TMR, T2: Fed TMR supplemented with AFF at a level of $10 \%$ of the TMR, T3: Fed TMR supplemented with AFF at a level of $15 \%$ of the TMR. ${ }^{a, b}$ Means within a row with different superscript differ $(p<0.05)$. 
can be affected by alcohols, because most alcohols are absorbed through the rumen wall into the blood (Burning and Yokoyama, 1988; Anbarasu et al., 2002; Chen et al., 2002). Change in correlation among the concentrations of albumin, BUN, TP and ammonia after feeding AFF diet implies the possible alteration of protein metabolism in the body. Furthermore, BUN also is a useful indicator of protein metabolism and status in cows (Roseler et al., 1993). In our study, feeding AFF did not affect the concentration of TG in serum. However, an increased TG concentration was observed by Yan et al. (1998) when they examined the effect of alcohol-fermented feeds on blood metabolites in Korea native steers.

In the recent past, dairy products have received adverse publicity in terms of their effect on the blood cholesterol concentration of consumers. They have been perceived to increase blood cholesterol content, which is a risk factor in the aetiology of coronary heart disease. In our study, AFF reduced concentration of cholesterol both in serum and milk. Alteration in correlation between the concentrations of blood cholesterol and milk cholesterol after feeding AFF diet could be due to the possible alteration of lipid metabolism in the body (Pearce, 1996). In contrast, Yan (1998) found higher concentrations of serum cholesterol in Korean native steers when fed alcohol-fermented feeds. Such differences in cholesterol secretion between breeds (i.e. lactating cow and beef steers) could be related to differences in the metabolism of fat (lipoprotein) in the rumen and/or tissues. Because of our limited number of observations, it is not possible to draw definitive conclusions about the level of regulation of cholesterol in milk. The normal concentration of GGT, GPT and GOT enzymes in serum are intracellular and therefore only their higher values have a pathological significance (Simion et al., 2010).

Large amounts of ethanol can be readily utilized by dairy cows (Pradhan and Hemken, 1970). A part of this ethanol is metabolized by rumen bacteria (Moomaw and Hungate, 1963) mainly forming acetate (Czerkawski and Breckenridge, 1972) and, to a lesser extent to the other volatile fatty acids (Pradhan and Hemken, 1970). Supplementation of alcohol increased the proportion of essential fatty acid (C18:2n6, C18:3n9) and unsaturated fatty acid in milk fat. Furthermore, increases in unsaturated fatty acid concentration caused an increase in the ratio of USFA to SFA when the TMR contained AFF. This may suggest that lactating cows fed AFF diet were able to alter the fatty acid profile due to a shift in the rumen fermentation with increase in acetate and mammary de novo fatty acid synthesis.

Feeding a diet supplemented with a moderate level AFF to lactating cows could be a way to alter the feed efficiency and fatty acid profile of milk to increase for the potential human consumer healthy fatty acid without detrimental effects on feed intake and milk production. A substantially decreased cholesterol proportion in milk induced by supplementation with AFF suggests that alcohol fermented feed may improve milk cholesterol level without any negative effects in lactating cows.

\section{REFERENCES}

Allison, M. J., J. A. Bucklin and R. W. Dougherty. 1964. Ruminal changes after overfeeding with wheat and the effect of intraruminal inoculation on adaptation to a ration containing wheat. J. Anim. Sci. 23:1164-1171.

Anbarasu, C., D. Narayan, K. Shama and U. Naulia. 2002. Blood biochemical profile and rumen fermentation pattern of goats fed leaf meal mixture or conventional cakes as dietary protein supplements. Asian-Aust. J. Anim. Sci. 15:665-670.

AOAC. 1995. Official methods of analysis, 15th ed. Association of Official Analytical Chemists, Washington, DC, 269 USA.

Byers, F. M., R. D. Goodrich and J. C. Meiske. 1982. Influence of acetic acid, lactic acid and ethanol on the fermentation of com silage. J. Anim. Sci. 54:640-648.

Burning, C. L. and M. T. Yokoyama. 1988. Characteristics of live and killed brewer's yeast slurries and intoxication by intraruminal administration to cattle. J. Anim. Sci. 66:585-591.

Chaney, E. L. and E. P. Marbach. 1962. Modified reagents for determination of urea and ammonia. Clin. Chem. 8:130-133.

Chen, K. J., D. F. Jan, P. W. S. Chiou and D. W. Yong. 2002. Effects of dietary heat extruded soybean meal and protected fat supplement on the production, blood and ruminal characteristics of Holstein cows. Asian-Aust. J. Anim. Sci. 15:821-827.

Czerkawski, J. W. and G. Breckenbridge. 1972. Fermentation of various glycolytic intermediates and other compounds by rumen micro-organisms, with particular reference to methane production. Br. J. Nutr. 27:131-146.

Dulphy, J. P. and C. Demarquilly. 1981. Problèmes particuliers aux ensilages. In: Prevision de la valeur nutritive des aliments des ruminants (Ed. C. Demarquilly, INRA Publications, Versailles. 81-104.

Durix, A., C. Jean-Blain, H. P. Sallmann and J. P. Jouany. 1991. Use of semicontinuous culture system (RUSITEC) to study the metabolism of ethanol in the rumen and its effects on ruminal digestion. Can. J. Anim. Sci. 71:115-123.

Folch, J., M. Lee and G. H. Sloan-Stanley. 1957. A sample method for the isolation and purification of total lipids from animal tissue. J. Biol. Chem. 226:497-509.

Jean-Blain, C., A. Durix and B. Tranchant. 1992. Kinetics of ethanol metabolism in sheep. Reprod. Nutr. Dev. 32:83-90.

Kristensen, N. B., A. Storm, B. M. L. Raun, B. A. Røjen and D. L. Harmon. 2007. Metabolism of silage alcohols in lactating dairy cows. J. Dairy Sci. 90:1364-1377.

Lauková, A. and M. Marounek. 1992. Physiological and biochemical characteristics of staphylococci isolated from the rumen of young calves and lambs. Zentralbl. Microbiol. 147:489-494.

Lepage, G. and C. C. Roy. 1986. Direct trans-esterification of all classes of lipid in a one-step reaction. J. Lipid Res. 27:114-221. 
Lin, G. Z., B. W. Kim, C. H. Kim, H. S. Kim, K. I. Sung, S. J. Ohh, B. J. Hong and J. S. Shin. 2004. Changes in serum metabolites and growth characteristics of Korean native steers fed alcoholfermented feeds. Asian-Aust. J. Anim. Sci. 17:648-654.

Lin, G. Z. 2001. Nutritional metabolism of alcohol-fermented feedstuffs in the rumen of Korean beef cattle. Ph. D. Dissertation, Kangwon National University, Chunchon, Korea.

Moomaw, R. C. and R. E. Hungate. 1963. Ethanol convertion in the bovine rumen. J. Bacteriol. 85:721-722.

National Research Council. 2001. Nutrient requirements of dairy cattle. 7th Ed. National Academy of Sciences, Washington, DC, USA.

Pearce, J. 1996. Effects of milk and fermented dairy products on the blood cholesterol content and profile of mammals in relation to coronary heart disease. Int. Dairy J. 6:661-672.

Pradhan, K. and R. W. Hemken. 1970. Utilization of ethanol and its effect on fatty acid patterns in ruminants. J. Dairy Sci. 53:1739-1746.

Randby, A. T., I. Selmer-Olsen and L. Baevre. 1999. Effect of ethanol in feed on milk flavor and chemical composition. J. Dairy Sci. 82:420-428.

Rooke, J. A., F. M. Maya, J. A. Arnold and D. G. Armstrong. 1988. The chemical composition and nutritive value of grass silages prepared with no additive or with the application of additives containing either lnaobacillus plantarum or formic acid. Grass For. Sci. 43:87-95.
Roseler, D. K., F. D. Ferguson, C. F. Sniffen and I. Herrema. 1993. Dietary protein degradability effects on plasma and milk urea nitrogen and milk non-protein nitrogen in Holstein cows. J. Dairy Sci. 76:525-534.

SAS Institute Inc. 2004. SAS/SAT user's guide: Version 9. 2th edn SAS Institute Inc., Cary, North Carolina, USA.

Shin, J. S. 1995. Effect of fermented alcoholic feedstuff, recombinant bovine somatotropin and castration on high quality beef production. Ph. D. Dissertation, Kangwon National University, Chunchon, Korea.

Simion,V. E., P. Gheorghe, P. Elena, B. Luiza and P. Monica. 2010. Alteration of some biochemical and haematological parameters in the dairy cows due to the intake of mycotoxin contaminated feeds. Anim. Sci. Biotechnol. 43:100-104.

Teunissen, M. J., E. P. W. Kets, H. J. M. Op den Camp, J. H. J. Huis in't Veld and G. D. Vogels. 1992. Effect of coculture of anaerobic fungi isolated from ruminants and non-ruminants with methanogenic bacteria on cellulytic and xylanolytic enzyme activities. Arch. Microbiol. 157:176-182.

Yan, C. G. 1998. Effects of alcohol-fermented feedstuff on quality meat production in Hanwoo. Ph. D. Dissertation, Kangwon National University, Chunchon, Korea.

Van Soest, P. J., J. B. Robertson and B. A. Lewis. 1991. Methods for dietary fiber, neutral detergent fiber, and nonstarch polysaccharides in relation to animal nutrition. J. Dairy Sci. 74:3583-3597. 